\title{
The molecular basis of paediatric malarial disease
}

\author{
Ian A. Clark ${ }^{1}$ and Michael J. Griffiths ${ }^{2}$ \\ ${ }^{1}$ School of Biochemistry and Molecular Biology, Australian National University, Canberra, \\ Australia; ${ }^{2}$ Department of Paediatrics, Newcastle General Hospital, Newcastle upon Tyne, UK
}

\begin{abstract}
Severe falciparum malaria is an acute systemic disease that can affect multiple organs, including those in which few parasites are found. The acute disease bears many similarities both clinically and, potentially, mechanistically, to the systemic diseases caused by bacteria, rickettsia, and viruses. Traditionally the morbidity and mortality associated with severe malarial disease has been explained in terms of mechanical obstruction to vascular flow by adherence to endothelium (termed sequestration) of erythrocytes containing mature-stage parasites. However, over the past few decades an alternative "cytokine theory of disease' has also evolved, where malarial pathology is explained in terms of a balance between the pro- and anti-inflammatory cytokines. The final common pathway for this pro-inflammatory imbalance is believed to be a limitation in the supply and mitochondrial utilisation of energy to cells. Different patterns of ensuing energy depletion (both temporal and spatial) throughout the cells in the body present as different clinical syndromes. This chapter draws attention to the over-arching position that inflammatory cytokines are beginning to occupy in the pathogenesis of acute malaria and other acute infections. The influence of inflammatory cytokines on cellular function offers a molecular framework to explain the multiple clinical syndromes that are observed during acute malarial illness, and provides a fresh avenue of investigation for adjunct therapies to ameliorate the malarial disease process.
\end{abstract}

\section{Introduction}

Although many species of malarial parasite exist, only Plasmodium falciparum, vivax, ovale, and malariae are classically associated with human infection. The former two species are most frequently associated with malarial disease in humans, with severe malarial disease almost exclusively associated with $P$. falciparum infection. Falciparum malaria is responsible for considerable morbidity (300-500 million annual clinical cases) and death across the globe, with a particular burden of mortality among children in sub-Saharan Africa. Infection with P. vivax is rarely fatal, but is associated with considerable morbidity outside the African continent. It should also be recalled that malaria causes social and economic disruption on a uniquely large scale [1]. 
Severe adult malaria is a clinical syndrome originally classified using 10 defining and 5 supportive (often overlapping) clinical features unified by the presence of asexual malarial parasites in the peripheral blood smear [2]. Based on observations of children in coastal Kenya, paediatric severe malaria has similarly been distilled into three main (again often overlapping) clinical syndromes, anaemia, respiratory distress (an indicator of an underlying metabolic acidosis) and impairment of consciousness [3]. These clinical syndromes are discussed below.

In the review mentioned above [3], the authors' judicious use of the term impaired consciousness, rather than cerebral malaria $(\mathrm{CM})$, promoted the useful concept that the neurological features (and in-turn the underlying mechanisms) associated with severe malaria are not necessarily unique to malarial disease. Indeed, over 60 years ago, it was noted that the clinical features of malaria can resemble those exhibited in patients with fulminant bacterial or viral infections [4].

Severe malaria has been intensively studied, and there appears to be a complex interplay between host infection and disease. This is highlighted by the different clinical manifestations of severe malaria exhibited by children and adults. These differences are undoubtedly, in part, a function of patient age. However, age is just one of a series of interacting factors, e.g. geographical region, level of malaria transmission, degree of previous malaria exposure, length of illness prior to treatment and host immunity that may influence the clinical presentation of severe malaria. This variation in clinical presentation has been mirrored by a similar multitude of proposals regarding the functional mechanisms underlying pathogenesis of severe malaria.

One concept of pathogenesis consistently articulated has been the 'mechanical theory'. Historically, this theory was developed from two fundamental differences between P. falciparum and P. vivax infection. Firstly, erythrocytes parasitised with $P$. vivax do not sequester. Secondly, death following P. vivax infection is rare. Consequently, pathogenesis is believed to be due to obstruction of micro-vascular flow by erythrocytes containing mature-stage falciparum parasites adhering to the endothelium (termed sequestration).

More recently the 'cytokine theory of disease' has also gained credence. This theory can be applied to disease following both falciparum and vivax infection. The lower mortality associated with $P$. vivax being explained by a relatively milder degree of pro-inflammatory imbalance during the host's response to $P$. vivax infection.

The main theme of this chapter is to examine the increased understanding of the functions of inflammatory cytokines gained over the past 15 years, and explore how these insights are changing attitudes in malarial disease research. We also discuss how two theories (mechanical and cytokine) can, as proposed first in a recognisable form at least 65 years ago [5], be complementary. 
Table 1. Comparison of Kenyan children and Papua-New Guinea adults admitted to hospital using the WHO classification

\begin{tabular}{|c|c|c|c|c|}
\hline & \multicolumn{2}{|c|}{ Kenyan children [7] } & \multicolumn{2}{|c|}{$\begin{array}{l}\text { Adults Papua-New Guinea } \\
{[19 \mathrm{a}]}\end{array}$} \\
\hline & Prevalence & Mortality & Prevalence & Mortality \\
\hline \multicolumn{5}{|l|}{ Defining criteria } \\
\hline Coma* & 10.0 & 16.8 & 17.1 & 41.7 \\
\hline Severe anemia** & 17.6 & 4.7 & 10 & 0 \\
\hline \multicolumn{5}{|l|}{ Pulmonary oedema } \\
\hline Hypoglycaemia & 13.2 & 21.7 & 5.7 & 75 \\
\hline Circulatory collapse & 0.4 & 71.4 & 0 & \\
\hline Renal Failure & 0.1 & 0 & 22.9 & 37.5 \\
\hline Spontaneous bleeding & 0.1 & 0 & 0.1 & 100 \\
\hline Haemoglobinaemia & 0.1 & 50 & 0.1 & \\
\hline Acidosis & 63.6 & 21.4 & & \\
\hline Repeated convulsions & 18.3 & 6.8 & 0.3 & 0 \\
\hline \multicolumn{5}{|l|}{ Supporting criteria } \\
\hline Impaired consciousness & 8.2 & 6.0 & 37.1 & 11.5 \\
\hline Jaundice & 4.7 & 11.9 & 45.7 & 25 \\
\hline Prostration & 12.2 & 5.2 & & \\
\hline Hyperpyrexia & 10.6 & 1.6 & 20 & 7.1 \\
\hline Hyperparasitaemia & 8.9 & 4.3 & 40 & 28.6 \\
\hline
\end{tabular}

* Childhood coma is defined by a Blantyre coma score $\geq 2$.

** The childhood definition for severe anemia does not include a cut off for parasitaemia.

Modified from [11].

\section{Severe malaria in children compared to adults}

The majority of the clinical cases of malaria occur in sub-Saharan Africa. Nevertheless, malaria also accounts for considerable morbidity and mortality in other continents particularly South East Asia [6]. In malaria-endemic regions (e.g. sub-Saharan Africa), where the resident population have continuous exposure to malarial parasites, most of the severe cases are seen in children [7]. In hypoendemic regions (e.g. South East Asia), where parasite exposure is more intermittent, cases of severe malaria are also common in adults (Tab. 1).

Clinical features associated with malaria mortality vary between children and adults, but acidosis and coma are associated with malarial mortality in both populations $[7,8]$. Acute renal failure (ARF) and pulmonary oedema, 
a marker for adult respiratory distress syndrome (ARDS), are almost exclusively reported among adults $[9,10]$, whereas mortality associated with hypoglycaemia is frequently reported among children [11].

Why malarial disease displays such age-related differences in pathophysiology is unclear. However, these differences are not exclusive to malaria. ARDS, which is more frequently observed as a complication of trauma in adults compared with children [12], is believed to reflect an exaggerated pro-inflammatory response within the lung [9]. A possible lead for future studies on these age-related differences in malaria is suggested by a report of peritoneal macrophages collected from healthy adults producing much less interleukin (IL)-10 (an anti-inflammatory cytokine), but the same levels of pro-inflammatory cytokine, than those from healthy children, giving adults a much higher pro-inflammatory status $[13,14]$.

The mechanism of malarial ARF pathogenesis is postulated to be multifactorial, involving mechanical, haemodynamic, and immunological factors [15]. The observation that ARF is more frequently observed as a complication of trauma in adults than children [12] suggests that age-related variations in cytokine response may again influence pathogenesis.

Hypoglycaemia is regarded as a more frequent complication of sepsis in paediatric populations compared with adults [16]. Hypoglycaemia in children may, in part, be associated with a higher basal metabolic rate, and lower glycolytic [17] and gluconeogenic substrate reserves compared to adults [18]. However, these substrates are not always limiting during acute paediatric malaria, suggesting functional impairments of glucose metabolism may also occur [19]. Such functional impairments may, in part, be influenced by increases in inflammatory cytokines as the infection progresses.

\section{How might $P$. falciparum cause this complex disease?}

Once the malarial parasite was identified as the cause of disease, it quickly became apparent that illness and death were linked with parasite invasion into bloodstream and subsequent parasite growth within (and release from) the erythrocytes. By the start of the 20th century, two major theories, capillary blockage and toxicity of the parasites themselves, had been proposed to explain morbidity and mortality. Thus, the study of malarial disease is not a settled story requiring regular updates, but one containing, from its beginning, an unresolved tension. Vascular occlusion and malarial toxin (nowadays vascular occlusion and inflammatory cytokines) have been alternative approaches to understanding malarial disease as a whole, as well as the coma, for over a century, and the two have often been discussed side by side $[5,20,21]$. The presence of hyperlactataemia, hypoglycaemia, and metabolic acidosis, all three consistent with a patient being forced to rely on anaerobic glycolysis for energy production, have provided a consensus that hypoxia is central to disease pathogenesis in falciparum malaria. As sum- 
marised below, the modern literature offers two main theories for cellular hypoxia during infection; insufficient oxygen delivery to cells and impaired oxygen utilization within the cells. Both mechanisms may be governed by the host inflammatory cytokine response to infection. This chapter focuses on how an increased understanding of the molecular functions of cytokines during disease demonstrates a closer alignment between the pathogenesis of falciparum infection and other systemic infectious diseases.

\section{Inflammatory cytokines and malarial disease}

One hundred and twenty years ago, Golgi (of the Golgi apparatus [22]), noted onset of malarial fever and illness at a predictable short interval after the regular shower of new parasites were released from bursting red cells. The nature of the putative toxin so released was much discussed in the first decade of the 20th century [23]. It was assumed to be directly toxic, in the manner of tetanus toxin. The proposal that malarial products were not harmful in themselves, but only through causing the infected host to harm itself through generating toxic amounts of molecules (pro-inflammatory cytokines) that, in lower concentrations, inhibit growth of malarial parasites did not arise until 1981 [24]. Indeed, acceptance of the broad applicability of this concept to infectious disease in general is now sufficient for its evolution to be a subject for research [25]. Tumour necrosis factor (TNF) is regarded as a major player, malaria being the first disease in which it was proposed to cause systemic illness and pathology [24]. Multiple TNF promoter polymorphisms have since been independently associated with severe malaria across several geographical populations [26]. A longitudinal study in Burkino Faso has also demonstrated several TNF promoter polymorphisms associated with the regulation of host-parasite density [27]. The TNF concept has since begun to dominate the sepsis literature [28], and the virulence of different strains of influenza, a disease that is a standard clinical misdiagnosis for imported malaria, has recently been expressed in terms of their capacity to induce TNF [29]. The critical role of TNF in both malaria and influenza pathogenesis is consistent with the clinical similarities between the diseases. Indeed, TNF infusions in tumour patients produce side effects mimicking both diseases [30], as discussed below.

Although TNF is the prototype pro-inflammatory cytokine linked with severe malaria, other cytokines (and mediators) including interferon (IFN)$\gamma$ [31], its corresponding receptors IFN- $\gamma$ receptor-1 [32] and IFN- $\alpha$ receptor-1 [33], IL-1 [34], IL-4 [35] and IL-10 [36] have all be identified through genetic association analysis to be linked with their potential regulation of malarial disease severity.

All the above cytokines typically act as homeostatic agents, but can cause pathology if produced excessively. When this happens they also induce a late-onset, but long-acting cytokine termed the high mobility 
Table 2. Some changes common to systemic inflammatory states, including falciparum malaria

\begin{tabular}{ll} 
Cytokines & - TNF, IL-1, iNOS, IFN- $\gamma$ raised \\
& - MIF, IL-10, and HO-1 raised \\
& $-\gamma / \delta$ T cells increased \\
& - S100A8-S100A9 complex raised \\
& - Procalcitonin raised \\
& - S100A12 raised \\
& - HMGB1 raised \\
& - ICAM, VCAM and p-selectin raised \\
\hline Consequences $\quad$ & - Insulin resistance \\
& - Hyperlactataemia \\
& - Hypertriglyceridaemia \\
& - Hypoglycaemia \\
& - Metabolic acidosis \\
& - Hyponatraemia \\
& - Coagulopathy \\
& - Thrombocytopaenia \\
& - Decreased red cell deformability
\end{tabular}

group box 1 (HMGB1) protein, which prolongs and amplifies inflammation $[37,38]$. This molecule, normally in the cellular nucleus and previously known only for several physiological functions, now shows great promise as a therapeutic target in sepsis, in that countering it after the onset of illness protects well in experimental sepsis $[39,40]$. It accumulates, in proportion to degree of illness, in serum from African children infected with falciparum malaria [41].

Once neutralising anti-TNF antibodies became available for human use, they were tested for efficacy against malarial disease. Unfortunately, a central tenet of the cytokine concept of infectious disease (that the proinflammatory cytokines that cause disease are the same mediators that, in lower concentrations, are responsible for the innate immunity that controls parasite growth) was not taken into consideration. TNF has been shown to inhibit a mouse malarial parasite in vivo [42], and $P$. falciparum in vitro, provided white cells to generate the next down-stream mediator, possibly nitric oxide (NO) [43], were present [44]. This is consistent with findings in human subjects [45]. Thus, it is not surprising that anti-TNF antibody, by removing inhibitory pressure from the pathogen, can enhance the disease in falciparum malaria [46], as shown 5 years earlier in human sepsis [47]. 
Cytokines as a disease mechanism extends beyond malaria

As noted above, the idea that excessive production of inflammatory cytokines underlies the pathology of illness is used widely, from malaria across a range of conditions, infectious or otherwise. As reviewed recently [48], this now includes the illnesses caused by rickettsias, protozoa other than malaria, and viruses. Increased circulating levels of these cytokines have been detected in the serum very soon after onset of illness in virtually all those infectious diseases in which they have been sought. Some cytokine increased, and consequences are shown in Table 2. When rTNF was under trial in volunteers as an anti-tumour agent $[49,50]$ nearly 20 years ago, virtually all of the symptoms and signs they share were reproduced as side effects. This includes headache, fever and rigours, nausea and vomiting, diarrhoea, anorexia, myalgia, thrombocytopaenia, immunosuppression, and central nervous system manifestations, all of which have been shown to be caused by a mechanism involving inflammatory cytokines. The rate, timing and intensity of cytokine release vary in different disease states, and provide them with somewhat individual clinical pictures, but the fundamentals remain. Nevertheless, the clinical patterns generated are remarkably close, in that, at least in some populations, clinical features cannot predict a diagnosis of malaria from other causes of fever [51].

\section{Inflammatory cytokines acting indirectly to cause disease}

\section{Vascular occlusion}

Mature erythrocytic forms of $P$. falciparum are not seen in peripheral blood smears, and cause the erythrocytes they inhabit to adhere to the walls of venules and capillaries. From this observation arose the widely held view that much of the pathology following malarial infection is explained through parasite sequestration causing impairment of microvascular flow. Sequestration certainly occurs, since the life cycle dictates this. However, whether the temporal and anatomical patterns of sequestration are the same in both individuals with fatal disease and in parasite tolerant individuals has not been ascertained. Consequently, whether sequestration is the principal instigator of local pathology, or whether sequestration is an associated feature of all malarial infections with local pathology determined by other factors in the host response to the infection, e.g. a local imbalance of inflammatory mediators, has not been fully elucidated.

Erythrocyte cyto-adherence (irrespective of whether this adhesive process is directly or indirectly due to parasite sequestration) has repeatedly been shown to be mediated through a series of host-derived ligands. CD36 and thrombospondin were the first described endothelial receptors that bound infected red blood cells (RBCs) [52, 53], with most studied wild 
parasite isolates demonstrating adhesion to CD36 [54]. More recently, it has been shown that $P$. falciparum also interacts with other host adhesion receptors, i.e. intercellular adhesion molecule-1 (ICAM-1 CD54), vascular cell adhesion molecule-1 (VCAM-1 CD106) and E-selectin [55, 56]. Certain adhesive phenotypes, such as rosetting (the spontaneous tethering of infected and non-infected RBCs) and clumping (tethering of infected RBCs through platelets) have been preferentially associated with severe malarial disease [57, 58]. CD36 is involved in both mechanisms of adhesion, and a non-sense mutation in the gene encoding for CD36 has also been associated with protection from severe malaria [59]. Polymorphisms in the gene encoding ICAM-1 have also been associated with susceptibility to severe disease [27]. Furthermore, ICAM-1, together with VCAM and E-selectin, are up-regulated by TNF, with circulating levels of these ligands shown to be increased in severe malaria compared to uncomplicated infection [60].

Sequestration during falciparum malaria appears to be concentrated in the brain and placenta. There is some evidence to suggest that the propensity of inflammatory cytokines to up-regulate cell adhesion molecules, secondary to local variation in the density of thrombomodulin, is potentially higher in the microvasculature of the brain and placenta compared to other tissues. As reviewed [61], TNF and IL-1 increase tissue factor expression on endothelial cells, thereby initiating pathways that generate thrombin [62]. When thrombin binds to thrombomodulin on the endothelial cell surface, protein $\mathrm{C}$ is activated, which in turn can lead to further downstream activation of the coagulation cascade. Therefore vasculature with lowest thrombomodulin densities on the endothelial cell surface (brain least, placenta next least, and other organs more [63]) will have more unbound thrombin available for its other functions on activated endothelium. These other functions include up-regulation of adhesion molecules such as selectins, ICAM-1, VCAM-1 [64] and monocyte chemotactic protein-1 (MCP-1) [65]. Therefore, up-regulation of adhesion molecules within the cerebral vessels may occur as a local endothelial response to systemic inflammation and may not necessarily be precipitated by parasite sequestration.

\section{Anaemia}

Anaemia is another obvious way in which too little oxygen reaches cells, and thus their mitochondria [66]. As recently reviewed [67], critical illness associated with an inflammatory response invariably causes multifactorial anaemia. Obviously a high parasite load in malaria indicates that the infected RBCs will soon burst when the next generation of erythrocytic forms escapes, but anaemia does not correlate with parasitaemia, and sometimes is extreme when very few parasites are, or have been, present. The severe anaemia in transgenic mice expressing human TNF [68] incriminates the 
inflammatory response itself, so anaemia and mitochondrial dysfunction (see Mitochondrial dysfunction section below), both consequences of systemic inflammation, can be expected to coexist, and both contribute to total energy depletion.

\section{Poor red cell membrane deformability}

The lifespan of an RBC is, in part, limited by how long it can remain flexible enough to squeeze through fenestrations in specialised vessels in the red pulp of the spleen, and thus avoid phagocytosis by adjacent macrophages. Normally this loss is balanced by erythropoiesis, and haematocrit remains normal. If RBCs develop a premature loss of deformability they are removed from the circulation earlier. This loss of deformability happens to both infected and non-infected red cells in malaria, whether caused by $P$. vivax or P. falciparum.

Under physiological conditions, erythrocytes (and other cells) control the passive influx of osmotic active solutes (especially $\mathrm{Na}^{+}$) via an active, energy-dependent elimination of these solutes using $\mathrm{Na}^{+} / \mathrm{K}^{+}$-ATPase. This prevents intracellular accumulation of osmotically active solutes, preventing a subsequent influx of water, cell swelling and loss of cell integrity. During human [69] and monkey [70] malaria infection, intracellular $\mathrm{Na}^{+}$accumulates within erythrocytes (both parasitised and non-parasitised) implying that this $\mathrm{Na}^{+} / \mathrm{K}^{+}$pump is impaired during the disease process. Parallel changes in the ionic content of erythrocytes have been documented in a sepsis model of infection [71]. Similarly, reduction in erythrocyte deformability was shown to be associated with increased NO, an inhibitor of this membrane pump [72], in another sepsis model [73]. Since inhibition of the $\mathrm{Na}^{+} / \mathrm{K}^{+}$pump in vitro correlates with both reduced red cell deformability and decreased red cell filterability [74], any factor that inhibits the $\mathrm{Na}^{+} / \mathrm{K}^{+}$ pump could potentially worsen anaemia. Identification of inducible NO synthase (iNOS) activity, as one factor influencing red cell deformability, suggests that a pro-inflammatory milieu [75] may again govern the reduction in red cell deformability observed during malaria infection.

Originally observed in uraemic patients, poor red cell deformability was recognised in a small pilot study of malaria patients in 1985 [76]. It was reported soon afterwards in sepsis $[77,78]$, and subsequently studied in falciparum malaria with a view to understanding both circulatory obstruction [79] and anaemia [80]. It seems clear that a short life (poor deformability), and a slow replacement rate (dyserythropoiesis, below) can combine to cause severe anaemia in various diseases, particularly in chronic infections such as malaria.

\section{Dyserythropoiesis}

When red cells have a shortened lifespan, e.g. secondary to reduced erythrocyte deformability, replacement by new recruits is vital to avoid anaemia. Unfortunately, the same inflammatory cytokines that shorten lifespan also 
retard replacement. Some years ago researchers began to stress the contribution of bone marrow dyserythropoiesis to the anaemia of falciparum malaria [81, 82]. A group in Oxford [83], seeking an explanation for this dyserythropoiesis through an electron microscopy study of bone marrow, observed sequestration of parasitised red cells and argued that this caused the bone marrow dysfunction in falciparum malaria by restricting blood flow and thus inducing hypoxic changes. This idea proved inadequate, however, when this same group subsequently reported dyserythropoiesis and erythrophagocytosis in vivax malaria, in which parasitised red cells do not sequester [84].

Some time ago an undefined product in macrophage supernatants [85], later identified as TNF [86], was found to inhibit the growth and differentiation of erythroid progenitor cells. When rTNF became available, the dyserythropoiesis and erythrophagocytosis seen in terminal Plasmodium vinckei-infected mice was reproduced by giving a single injection early in the course of the infection [87]. Phagocytosis of erythroblasts in bone marrow, a phenomenon also reported by Wickramasinghe et al $[83,84]$ in human malaria, also occurred. Decreased erythropoiesis was subsequently reported in mice receiving continuous TNF infusions via implanted osmotic pumps, and mice expressing high levels of human TNF have been shown to become markedly anaemic during malaria infections [68], even though parasite numbers, and therefore red cell loss post-schizogony, are considerably reduced.

The past decade has seen an expansion of this line of enquiry into human malaria, and also the number of cytokines, both pro-inflammatory and anti-inflammatory [88, 89] in absolute amounts and ratios [90, 91], that have been investigated in this context. Investigations have been extended to include other pro-inflammatory cytokines, such as IL-12 [92] and FasL [93], and examined the role in anaemia of the persistence of cytokine production during malaria infection [94]. Another inflammatory cytokine, macrophage inhibitory factor (MIF) that is increased in malaria, and induced by TNF, has been shown to cause dyserythropoiesis in in vitro studies on bone marrow cells $[95,96]$. Thus, inflammatory cytokines generated during malaria are a major determinant of the degree to which anaemia influences the amount of oxygen that reaches tissues in malaria.

\section{Inflammatory cytokines acting directly to cause disease}

\section{Mitochondrial dysfunction}

Mitochondria are vital to energy (ATP) generation through cellular respiration. Cellular respiration requires oxygen and pyruvate, as well as multiple cofactors and active transport molecules. Within the matrix of the mitochondrion organelle, pyruvate is catabolised via the Krebs cycle and oxidative 
phosphorylation (involving NADH and FADH2) to generate ATP. When this series of reactions are $100 \%$ efficient (unlikely in vivo), 1 molecule of glucose generates 2 molecules of pyruvate, which are further catabolised to water and carbon dioxide with the concomitant generation of 36 molecules of ATP. In comparison, during anaerobic glucose catabolism, pyruvate is converted to lactate with the concomitant generation of 2 molecules of ATP, a process that also facilitates regeneration of NADH and FADH2.

Evidence is accumulating that inflammatory cytokines, as released in malaria, sepsis, and viral diseases, induce mitochondrial dysfunction and dysregulate cellular respiration, resulting in the incomplete catabolism of pyruvate. The process, termed 'cytopathic hypoxia'[97], mimics cellular hypoxia, in that it results in the incomplete catabolism of pyruvate and accumulation of lactate. Awareness of this mechanism began with oxygen tension being shown to be increased in septic rats [98] and patients [99]. A cytokine model of mitochondrial dysfunction has since been developed in which impairment of cellular respiration occurs following induction of sepsis (or exposure to pro-inflammatory cytokines), despite sufficient oxygen supply $[97,100,101]$. More recently, impairment of enzyme activity associated with the mitochondrial complexes has been demonstrated in muscle biopsies retrieved from rodent models of sepsis [102] and septic patients $[103,104]$. The observation that the inflammatory cytokines implicated in mitochondrial shutdown are prominent in both sepsis and malaria $[105,106]$ supports such organelle dysfunction being equally plausible in malaria.

Researchers are also becoming aware that, beyond energy production, mitochondria also play a vital role in cell homeostasis through generation and detoxification of reactive oxygen species [107]. The accelerated oxidative damage that accompanies sepsis could be both a cause and a consequence of cytokine-induced mitochondrial dysfunction. Interestingly, the ultrastructural damage reported to accompany mitochondrial dysfunction in sepsis [102] reflects Maegraith's observations in monkey malaria [108110] decades ago.

\section{Metabolic acidosis in falciparum malaria}

Metabolic acidosis, often associated with hyperlactataemia, has been described in African children with severe falciparum malaria [111,112]. It is not unique to this disease, being seen in viral, rickettsial and bacterial infections [113] as well as acute gastroenteritis, where its prevalence is higher than in malaria [114]. The terms hyperlactataemia and lactic acidosis are often mistakenly used interchangeably in the malaria literature. As often reviewed in the basic literature [115-118], protons $\left(\mathrm{H}^{+}\right.$, the basis of acidosis) are not formed when ATP and lactate are generated during glycolysis, but on the subsequent hydrolysis of ATP in tissues. Every time a molecule of ATP undergoes hydrolysis, a proton is released. If this occurs under aero- 
bic conditions, these protons are consumed within ATP regeneration from $\mathrm{ADP}$, and $\mathrm{pH}$ remains normal, i.e. acidosis does not occur. In contrast, if the mitochondria are not functioning adequately, whether through insufficient oxygen supply or an inability to use it, ATP regenerates under anaerobic condition, and the protons are not consumed. Hence, once the buffering capacity of the body is exceeded, acidosis occurs. In short, metabolic acidosis requires the ratio of glycolytic (i.e. anaerobic) ATP hydrolysis to mitochondrial (i.e. aerobic) ATP hydrolysis to reach a point at which the buffering systems can no longer cope. Pathological changes in the buffering system can be a major determinant of when this occurs.

\section{Is hyperlactataemia a cause or marker of the acidosis of malaria?}

High lactate levels have traditionally been seen not only as a marker for poor oxygen delivery in disease states, but also a consequence of it, and the cause of the acidosis. For some time hyperlactataemia has been regarded as a functionally relevant marker for a poor prognosis in both sepsis [119] and malaria $[66,112,120]$. Although the sepsis world now discusses several origins for the lactate increase, including inflammation-induced mitochondrial dysfunction [97], in falciparum malaria it is still generally attributed to a reduced oxygen supply, mostly through microvascular occlusion by sequestered parasitised erythrocytes [121]. Other mechanisms are known to contribute to acidosis in malaria, independent of lactate production, e.g. acute renal failure [8]. Impaired hepatic clearance $[8,112]$, production by parasites, and, in some areas, thiamine deficiency [122] are also argued to contribute to lactate accumulation independent of impaired cellular respiration. Thus, as described below, although acidosis and hyperlactataemia can be associated, they are independent cellular mechanisms.

Lactate anion has complex roles in biology. Hyperlactataemia may be associated with acidosis, a normal $\mathrm{pH}$, or alkalosis [123]. A recent editorial in Critical Care Medicine [124] has lucidly summarised the key points of the mechanism of metabolic acidosis in sepsis, a condition that shares systemic inflammation and a range of its consequences with severe malaria (Tab. 2). These authors argue against lactate as the cause of the acidosis associated with hypoxia. Instead, they note the evidence that during hypoxia, be it from limited oxygen supply or utilisation, the unconsumed protons that cause acidosis arise from the hydrolysis of non-mitochondrial ATP. Since these reactions are independent of lactate levels, it is difficult to see how therapeutically reducing levels of this anion, as has been proposed [125], could increase survival rate in falciparum malaria any more than in sepsis [126]. Indeed, in theory it could harm comatose patients, since there is evidence that lactate helps brain tissue survive hypoxic and hypoglycaemic episodes [127-129], and the lactate shuttle is proving to be how astrocytes protect neurons from metabolic stress [130]. 
Even when considerable lactate is generated in acute inflammatory states, other, unidentified, anions contribute much more than it does to the strong ion difference that, through influencing the body's buffering capacity, influences acidosis in sepsis [131, 132] and falciparum malaria [114, 133]. Thus, lactate accumulation can only partially account for the high anion gap observed during the metabolic acidosis associated with severe malaria.

In summary, lactate is an imprecise but useful marker for metabolic acidosis in malaria. In turn, acidosis is an imprecise but useful marker of impaired cellular respiration. Whether impaired cellular respiration arises from (a) poor supply of oxygen to mitochondria (through vaso-occlusion, low circulating volume, anaemia or cardiac insufficiency) or impaired mitochondrial function (in response to severe systemic inflammation) the outcome is essentially the same. The resulting high anion gap metabolic acidosis is strongly predictive of death in severe malaria. Greater understanding of the multiple factors influencing the metabolic acidosis could provide further insight into the underlying pathophysiological process and may provide additional therapeutic options.

\section{Hypoglycaemia in paediatric malaria}

When glycolysis is enhanced for any period glycogen stores are soon depleted, and gluconeogenesis supervenes. However, its substrate supplies are limiting [134], and the hypoglycaemia often reported in severe malaria [135] and sepsis [19, 136] occurs. Hypoglycaemia is therefore a secondary cause of harm in these diseases, and is an inevitable consequence of exuberant, mostly anaerobic, glycolysis.

\section{Neurological involvement in malaria}

$\mathrm{CM}$ is a clinical syndrome characterised by coma (inability to localise a painful stimulus) at least $1 \mathrm{~h}$ after termination of a seizure or correction of hypoglycaemia, detection of asexual forms of $P$. falciparum malarial parasites on peripheral blood smears, and exclusion of other causes of encephalopathy [137].

\section{Energy depletion and cerebral oedema}

A relatively consistent feature of acute $\mathrm{CM}$ in children is raised intracranial pressure (ICP). Studies in African children have demonstrated a raised cerebrospinal fluid (CSF) opening pressure during lumbar puncture in $80 \%$ of CM children [138], raised ICP during intracranial pressure monitoring 
$(23 / 23 \mathrm{ICP}>10 \mathrm{mmHg}$ ) [139] and papilloedema (a late sign of raised ICP) in $44 \%$ of CM patients who died [140]. Where computer tomography has been performed, there was evidence of diffuse brain swelling in $40 \%$ of patients [139]. The cause of the raised ICP is likely to be multi-factorial and has been postulated to involve both vasogenic and cytotoxic patterns of cerebral oedema.

Vasogenic oedema is characterised by accumulation of interstitial fluid within the brain secondary to increased permeability of the blood-brain barrier (BBB). It has been demonstrated in bacterial cerebral infections, but evidence of significant disruption of the BBB is not conclusive in CM [141]. Others have proposed that ICAM-1 binding by infected erythrocytes may generate a cascade of intracellular signalling events that disrupt the cytoskeletal-cell junction structure and cause focal disruption to the BBB [142]. Adult post-mortem analysis has shown cerebrovascular endothelial cell activation (increased ICAM-1 endothelial staining, reduction in cell junction staining, and disruption of junction proteins), particularly in vessels containing infected erythrocytes [143]. However, disruption of intercellular junctions is not associated with significant leakage of plasma proteins (fibrinogen, IgG, or C5b-9) into perivascular areas or CSF [143]. In Thai adults, transfer of radioactively labelled albumin into CSF was not raised during unconsciousness compared with convalescence [144]. Similarly, the albumin index (ratio of concentrations of albumin in CSF to those in blood) was not altered significantly in Vietnamese adults [145] or significantly different between Malawian children with CM who died and those who survived [143].

Cytotoxic oedema is increasingly being recognised as an important mechanism of cerebral oedema in traumatic brain injury [146]. As previously discussed, this type of cell swelling involves disturbance of the "pumpleak equilibrium" maintained, under physiological conditions via active elimination of osmotically active solutes through the energy-dependent $\mathrm{Na}^{+} / \mathrm{K}^{+}$-ATPase. Thus, cytotoxic oedema can occur secondary to an imbalance in supply and demand of energy within the cells. Several mechanisms, such as sustained increase in neuronal activation, impaired substrate delivery (structural and functional) and impaired mitochondrial utilisation of available substrates, including oxygen, may coexist to generate this imbalance. All these mechanisms could contribute to ATP depletion and $\mathrm{Na}^{+} / \mathrm{K}^{+}$ ATPase failure, leading to cytotoxic oedema in CM.

$\mathrm{CM}$ is clearly associated with increased neuronal activity. A recent review identified that $80 \%$ of African children with CM have a history of seizures, with prolonged and recurrent seizures associated with a poor outcome [147].

Impaired vascular flow during acute $\mathrm{CM}$ may limit substrate delivery within the brain and contribute to energy imbalance. In the past, a common premise was that parasite sequestration precipitated cerebral vaso-occlusive/ischaemic (i.e. stroke-like) events that manifested clinically as CM. However, CM demonstrates several features that are atypical for stroke. In 
children, focal neurological signs do not tend to accompany coma, although a sub-set of patients do exhibit hemiparesis or focal brainstem deficits during the agonal period [148]. The incidence of residual neurological deficits following recovery from coma is relatively low (11\% [147]) when compared to childhood stroke (93\% had residual neurological deficit [149]). Where computer tomography has been performed in children, diffuse brain swelling was observed [150] rather than focal lesions more typical of stroke. Although retinal haemorrhages have been observed in $46 \%$ of Malawian children with $\mathrm{CM}$ (and in $63 \%$ of patients who died), these lesions were also seen in $30 \%$ of children with SMA in the same study [140]. Consequently, although associated with $\mathrm{CM}$, retinal haemorrhages do not confirm that focal cerebral vaso-occlusive/ischaemic events underlie CM. Similarly, histological examination of 32 fatal CM cases of African children at autopsy demonstrated that one third had little or no evidence of local vascular change in the brain, as indicated by sequestered parasites, monocyte clusters, micro-haemorrhages, local vascular iNOS [151] or haemoxygenase -1 (HO1) [152] staining. Accepting that CM may occur without ischaemia does not exclude temporary or less severe reductions in vessel flow occurring during acute CM (associated or independent of parasite sequestration) that may contribute to impaired substrate delivery and lead to energy imbalance.

As previously discussed, energy imbalance may also be impaired due to the uncoupling action of inflammatory cytokines on mitochondrial ATP production. In Gambian and Ghanaian children, concentrations of TNF and its receptor were higher in those with $\mathrm{CM}$ than in those with mild or uncomplicated malaria $[153,154]$. Polymorphisms in the TNF promoter region have also been associated with increased risk of CM and death [155] or neurological sequelae [156]. Cytokines may also up-regulate iNOS in brain endothelial cells, increasing production of NO, which could then diffuse into brain tissue and disrupt neuronal (and/or mitochondrial) function $[157,158]$.

In the brain, mitochondrial function may also be influenced by neuronal excitotoxins. Within the simplified model of dissociated neuronal culture, mitochondria appear to play a critical role in neuronal homeostasis during excitotoxin exposure. Mitochondria are not only involved with maintaining ATP production but also calcium homeostasis, and generation and detoxification of reactive oxygen species [107]. Excitotoxin production may also be influenced by cytokine release. TNF administration has been shown to alter brain metabolism of tryptophan to produce more kynurinine [159, 160]. Thus, as part of a general inflammatory reaction, increased excitotoxin generation during acute malaria may contribute to cellular energy imbalance. Elevated levels of neuronal excitotoxins (quinolinic and picolinic acid) in the CSF have been associated with a fatal outcome in Malawian children with CM [161]. Similarly, a graded increment of quinolinic acid concentration in CSF was observed across patient outcome groups of increasing severity in African children [162]. 


\section{Encephalopathy with systemic inflammation but without sequestration}

Although a subset of the Malawaian autopsy patients [163] demonstrated negligible histological change in their brains, they did demonstrate inflammation, as indicated by iNOS, MIF [151] and HO-1 [152], staining in other tissues. These systemic changes were shared with the comatose sepsis cases in the study, and therefore are consistent with the premise that coma may in part be secondary to a host inflammatory response to systemic infection. Below are further examples of systemic responses to infection that present with diffuse cerebral syndromes, including coma.

\section{Cerebral malaria manifesting with $P$. vivax infection}

In the past, the term $\mathrm{CM}$ has been restricted to falciparum malaria, and patients with $P$. vivax infection exhibiting symptoms of severe malaria, including coma, have been dismissed as undiagnosed falciparum co-infections. However, the use of more sensitive diagnostic techniques makes such dismissal less tenable. Two such studies report adults exhibiting severe malaria with $P$. vivax (but not $P$. falciparum) infection detectable on PCR and serological and testing $[142,143]$. The patients exhibited multiple organ failure including cerebral symptoms, renal failure, circulatory collapse, severe anaemia, haemoglobinuria, abnormal bleeding, acute respiratory distress syndrome, and jaundice. Vivax malaria has been associated with a strong systemic inflammatory response [164], but this was not investigated in the above studies.

\section{Sepsis-associated encephalopathy}

Sepsis-associated encephalopathy (SAE) syndrome has multiple features that resemble CM. It is characterised by a diffuse disturbance of cerebral function (typically impairment of consciousness) that occurs in the context of systemic response to infection without direct neuroinvasion (i.e. meningitis, macroscopic cerebritis and brain abscesses are excluded). SAE is associated with generalised slow waves on the electroencephalogram (EEG), with the depth of coma linked with mortality. Mild SAE cases often recover completely, while survivors of severe SAE may have persistent neurological deficit [165]). In line with adult CM, the severity of encephalopathy parallels the severity of systemic organ failure [141]. Inflammatory cytokines have been demonstrated to be higher in the serum than in the CSF, suggesting that sepsis encephalopathy is a consequence of the systemic inflammatory response to infection [141]. An animal model in which prior administration of a neutralising antibody to TNF prevented the sepsis encephalopathy of pancreatitis [166] is consistent with this. Further postulated reversible 
Table 3.

Influenza encephalopathy Cerebral malaria

Seizures/coma after high grade fever

Metabolic acidosis

Hyperlactataemia

Serum TNF, IL-6, sTNFRI up

Serum nitrite/nitrate up

CSF TNF, IL-6, sTNFRI up

Multiple organ failure

Residual neurological deficit

Thrombocytopaenia

Damage to vascular endothelial cells

Brain oedema/damage to BBB

Apoptosis in neurons/glial cells

Evidence of active caspase-3 (brains)

Caspase-cleaved PARP (brains

mechanisms of pathogenesis include changes in regional cerebral blood flow, neurotransmitter imbalance, mitochondrial dysfunction, BBB impairment and oxidative stress [167].

\section{Influenza encephalopathy}

Severe influenza infection can present with encephalopathy, yet as in malaria, the pathogen is not neuroinvasive [168]. Seizures and coma occur after high fever [169], commonly accompanied by thrombocytopaenia [169], with metabolic acidosis and hyperlactataemia in severe cases (T. Ichiyama, personal communication). Similar to adult malaria, neurological sequelae occur concurrently with multiple organ failure [170]. TNF, IL-6, sTNFRI, and soluble E-selectin are increased in serum and CSF [171,172], and serum nitrite/nitrate levels are increased [173]. Detailed examination of brain has revealed apoptosis of neurons and glial cell, histological evidence of active caspase- 3 and caspase-cleaved PARP, cerebral oedema, and BBB impairment [174]. These parallel changes are set out in Table 3. It is clear, therefore, that the presence of sequestering parasitised red cells is not necessary to generate these changes, which are also demonstrable in the falciparum malaria encephalopathy. Notably, high levels of inflammatory cytokine are present in each disease. 


\section{Seizures and malaria}

Seizures are a very common component of acute malaria illness in children. A recent review documented that $80 \%$ of African children had a history of seizures, with $60 \%$ exhibiting seizures during hospital admission [175]. The molecular basis of the seizures is unclear. Multiple mechanisms have been postulated, including fever, hypoxia and/or cytokine stimulation leading to an imbalance of neurotransmitters and excitotoxins or neuronal damage $[11,148]$. Recently, Lang and co-workers [176] demonstrated that falciparum parasitaemia is associated with the generation of specific antibodies for voltage-gated calcium channels directed against neurones. Higher antibody concentrations were detectable in sera from patients exhibiting $\mathrm{CM}$ or malaria with seizures than uncomplicated malaria, suggesting that these antibodies may influence seizure propensity.

\section{Red cell abnormalities and malaria}

Only the erythrocytic form of malaria is associated with disease, so valuable information about which African children are likely to have more, or less, severe malaria has inevitably been obtained from examining the inborn RBC abnormalities that endemic malaria has selected across the tropics.

The coinciding geographic distributions of malaria transmission and the thalassaemias prompted Haldane to put forward the 'malaria hypothesis', which proposed that common erythrocyte abnormalities are selected because of the fitness advantage they confer against malaria [177]. Sickle cell haemoglobin (HbS) has also been repeatedly shown to be associated with malaria resistance, with heterozygotes for the HbS trait demonstrating $10 \%$ of the population at risk for severe malaria in certain populations [178]. Other haemoglobinopathies (e.g. HbC [179, 180] and $\mathrm{HbE} \mathrm{[181])} \mathrm{and}$ deficiencies in RBC enzymes (e.g. glucose-6-phosphate dehydrogenase deficiency [182]) have also been linked with protection against severe malaria. The mechanisms of protection afforded by haemoglobinopathies are likely to be multi-factorial. Studies have demonstrated evidence to support several independent mechanisms including: reduced parasite invasion of RBCs and diminished intraerythrocytic growth of parasites in patients with the HbS trait [183], enhanced phagocytosis of parasite-infected erythrocytes (IEs) [184] and enhanced immune responses against IEs [185].

Recent in vitro studies observed that $\mathrm{HbC}$ modifies the quantity and distribution of the variant antigen $P$. falciparum erythrocyte membrane protein 1(PfEMP1) on the IE surface. PfEMP1 has been implicated in numerous IE adhesive interactions. In the latter study the authors demonstrated that $\mathrm{HbC}$ reduces the level of IE adhesion to endothelial monolayers, in addition to IE rosetting (the adhesion of IEs to uninfected erythrocytes) and IE agglutination by sera. These findings provide the prospect that $\mathrm{HbC}$ pro- 
tects against severe malaria by mitigating the obstruction and inflammation caused by the PfEMP1-mediated adherence of IEs [186]. However, sequestration is believed to enhance parasite survival by enabling IEs to avoid splenic clearance, so any reduction of sequestration by $\mathrm{HbC}$ can be expected to limit parasite fitness. Multiple epidemiology studies (e.g. [179, 187, 188]) have failed to identify any significant impact of $\mathrm{HbC}$ on the frequency or density of parasitaemia in naturally exposed populations. Consequently, the influence of the changes in IE surface conformation needs to be confirmed and further examined in vivo [189].

A recent study re-confirmed that African children with $\alpha$-thalassaemia trait are significantly less likely to be hospitalised with severe malaria, particularly with coma or severe anaemia $(\mathrm{Hb}<5 \mathrm{~g} / 100 \mathrm{ml})$. It is intriguing that the $\alpha$-thalassaemia patients did not demonstrate a lower incidence of uncomplicated malaria nor any reduction in peripheral parasite density [190]. Thalassaemia has also been associated with increased incidence of clinical vivax and falciparum malaria during early life [191]. The findings raise speculation that the trait may indirectly afford enhanced immunity through increased non-lethal exposure to malarial parasites. Such a mechanism is appealing, since it would be equally plausible across a range of haemoglobinopathies, including $\mathrm{HbC}$.

Variations in erythrocyte membrane proteins also have a profound influence on malaria susceptibility. Most notably the absence of Duffy antigen protein confers absolute protection to $P$. vivax infection. More recently, the Duffy antigen has also been associated with a protection against falciparum malaria [192].

Enzymes involved with iron handling may also have a critical influence on malaria morbidity. A recent study from the Gambia demonstrated that children in an endemic malaria area possessing the haptoglobin 2,2, isotype had a significantly increased risk of anaemia [193]. However, a lack of parallel alterations in other haematinic indices leaves the mechanism of this process unclear.

Malarial protection within individuals exhibiting multiple RBC abnormalities appears even more complex. A recent study observed that the concurrent presence of sickle cell and $\alpha$-thalassaemia trait among African children had a negative influence on the risk of malaria infection [194]. The results warn geneticists that gene epistasis may have a profound influence on overall malarial susceptibility.

\section{Potential therapies directed at disease mechanisms}

In tropical countries many hospital deaths from falciparum malaria happen before anti-malarial drugs have had time to kill the parasites. Two approaches could help rectify this - addressing public-health problems resulting in delayed presentation, and identifying the physiological processes and 
molecular pathways that lead to these early deaths, with a view to developing evidence-based adjunct therapies.

Therapies being explored in sepsis, and based on disease pathogenesis data common to sepsis and malaria, may prove to be transferable from either of these diseases to the other. As noted above, circulating levels of a late-appearing inflammatory cytokine, HMGB1, are increased in falciparum malaria [41] as well as in sepsis. Results from animal models on the role of HMGB1, although untested in humans, have inspired enthusiasm for inhibition of this molecule as a potential intervention for human sepsis. For instance, anti-HMGB1 antibodies provided dose-dependent protection [37] and reduced mortality [195] against experimental sepsis in mice. Late administration of ethyl pyruvate, which inhibits HMGB1 release from macrophages, also conferred protection against endotoxaemia in mice [196].

Treatments directed towards critical downstream consequences of malaria infection and inflammation, such as those intended to limit acidosis, are also a focus of investigation. One current approach is to identify which acute malaria patients most benefit from early volume expansion [197]. Controlling lactic acidosis via sodium dichloroacetate (DCA), an inhibitor of pyruvate dehydrogenate kinase (maintaining pyruvate dehydrogenase in its active form), is also being examined. DCA reduced lactate levels in acute malaria patients [198], although the study was unable to determine whether treatment improved outcome. An earlier large sepsis study also demonstrated that DCA reduced lactate, but again with no improvement in outcome [126]. As outlined in the section 'Is hyperlactataemia a cause or marker of the acidosis of malaria?', some researchers argue, in view of the strong ion difference contributing to acidosis and the postulated mitochondrial dysfunction during acute malaria infection, that lactate reduction per se may have limited impact on prognosis.

Other adjunct therapies are also being examined. Improving $\mathrm{RBC}$ deformability provides one potential therapeutic approach. In vitro studies with $N$-acetylcysteine (NAC), reported to scavenge free radicals, showed improvement in red cell deformability through in vitro studies [199]. Unfortunately, an initial in vivo trial of NAC in malaria patients had no effect on mortality [200]. Blocking endothelial activation is also a focus of research, with initial in vitro studies providing some encouraging results [201].

In conclusion, continuing to identify the host responses to malaria infection that lead to disease is providing insights into novel molecular mechanisms. This information is beginning to guide the design of much needed additional therapies against this disease. There is little doubt that poor oxygen supply through vascular occlusion or anaemia could contribute to the body relying on excessive glycolysis to generate energy, resulting in hyperlactataemia, hypoglycaemia, and metabolic acidosis, and altered consciousness. However, inflammatory cytokines control these changes, as well as inhibit the capacity of mitochondria to use oxygen. Thus, as described 


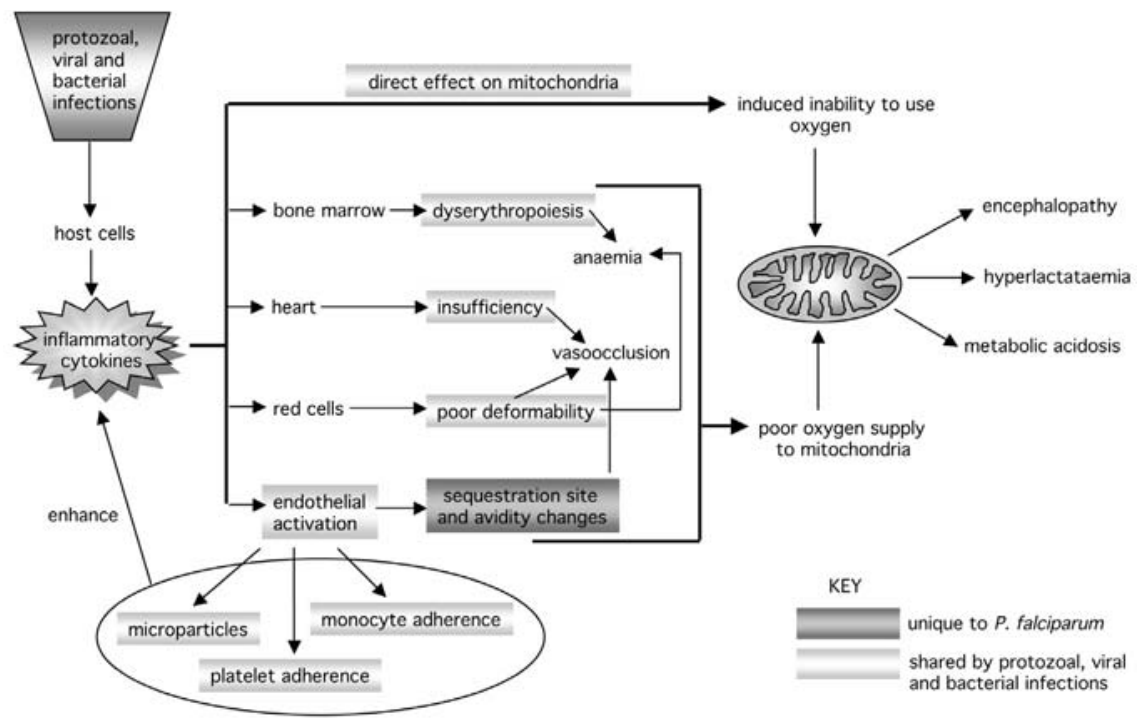

Figure 1 . The wide-ranging influences of inflammatory cytokines in severe malaria.

throughout this review, inflammatory cytokines are likely to have various pivotal roles across the multiple pathological processes involved in malarial disease (Fig. 1).

\section{References}

1 Sachs J, Malaney P (2002) The economic and social burden of malaria. Nature 415: 680-685

2 WHO (1986) Severe and complicated malaria. Trans $R$ Soc Trop Med Hyg 80: 3-49

3 Marsh K, Snow RW (1997) Host-parasite interaction and morbidity in malaria endemic areas. Philos Trans R Soc Lond 352: 1385-1394

4 Cannon PR (1941) Some pathological aspects of human malaria. In: FR Moulton (ed): A symposium on human malaria. American Association for the Advancement of Science, Washington, 214-220

5 Meleney HE (1941)The physiological pathology of malaria.In:FR Moulton(ed): A symposium on human malaria. American Association for the Advancement of Science, Washington, 223-230

6 Snow RW, Guerra CA, Noor AM, Myint HY, Hay SI (2005) The global distribution of clinical episodes of Plasmodium falciparum malaria. Nature 434: 214-217

7 Marsh K, Forster D, Waruiru C, Mwangi I, Winstanley M, Marsh V, Newton 
C, Winstanley P, Warn P, Peshu N et al (1995) Indicators of life-threatening malaria in African children. N Engl J Med 332: 1399-1404

8 Day NP, Phu NH, Mai NT, Chau TT, Loc PP, Chuong LV, Sinh DX, Holloway P, Hien TT, White NJ (2000) The pathophysiologic and prognostic significance of acidosis in severe adult malaria. Crit Care Med 28: 1833-1840

9 Taylor WRJ, White NJ (2002) Malaria and the lung. Clin Chest Med 23: 457468

10 Robinson T, Mosha F, Grainge M, Madeley R (2006) Indicators of mortality in African adults with malaria. Trans $R$ Soc Trop Med Hyg 100: 719-724

11 Newton CR, Krishna S (1998) Severe falciparum malaria in children: current understanding of pathophysiology and supportive treatment. Pharmacol Ther 79: $1-53$

12 Calkins CM, Bensard DD, Moore EE, McIntyre RC, Silliman CC, Biffl W, Harken AH, Partrick DA, Offner PJ (2002) The injured child is resistant to multiple organ failure: a different inflammatory response? J Trauma 53: 10581063

13 Barsness KA, Bensard DD, Partrick DA, Calkins CM, Hendrickson RJ, McIntyre RC (2004) Endotoxin induces an exaggerated interleukin-10 response in peritoneal macrophages of children compared with adults. J Pediatr Surg 39: 912-915

14 Barsness KA, Bensard DD, Partrick DA, Calkins CM, Hendrickson RJ, Banerjee A, McIntyre RC (2004) IL-1 beta induces an exaggerated pro- and anti-inflammatory response in peritoneal macrophages of children compared with adults. Pediatr Surg Int 20: 238-242

15 Eiam-Ong S (2002) Current knowledge in falciparum malaria-induced acute renal failure. J Med Assoc Thai 85: S16-S24

16 Parker MM, Hazelzet JA, Carcillo JA (2004) Pediatric considerations. Crit Care Med 32: S591-S594

17 Pagliara AS, Karl IE, Haywood M, Kipris DM (1973) Hypoglycemia in infancy and childhood. J Pediatr 82: 365-379

18 Dekker E, Romijn JA, Ekberg K, Wahren J, Vanthien H, Ackermans MT, Thuy LTD, Chandramouli V, Kager PA et al (1997) Glucose production and gluconeogenesis in adults with uncomplicated falciparum malaria. Am J Physiol 35: E1059-E1064

19 White NJ, Marsh K, Turner RC, Miller KD, Berry CD, Wiliamson DH, Brown J (1987) Hypoglycaemia in African children with severe malaria. Lancet 1: 708-711

19a Lalloo DG, Trevett AJ, Paul M, Korinhona A, Laurenson IF, Mapao J, Nwokolo N, Dangachristian B, Black J, Saweri A et al (1996) Severe and complicated falciparum malaria in Melanesian adults in Papua New Guinea. Am J Trop Med Hyg 55: 119-124

20 Berendt AR, Turner GDH, Newbold CI (1994) Cerebral malaria: the sequestration hypothesis. Parasitol Today 10: 412-414

21 Clark IA, Rockett KA (1994) The cytokine theory of human cerebral malaria. Parasitol Today 10: 410-412

22 Golgi C (1886) Sull infezione malarica. Arch Sci Med (Torino) 10: 109-135

23 Ross R (1911) The Prevention of Malaria. John Murray, London 
24 Clark IA, Virelizier JL, Carswell EA, Wood PR (1981) Possible importance of macrophage-derived mediators in acute malaria. Infect Immun 32: 1058-1066

25 Graham AL, Allen JE, Read AF (2005) Evolutionary causes and consequences of immunopathology. Annu Rev Ecol Evol Syst 36: 373-397

26 Kwiatkowski DP (2005) How malaria has affected the human genome and what human genetics can teach us about malaria. Am J Hum Genet 77: 171-192

27 Fernandez-Reyes D, Craig AG, Kyes SA, Peshu N, Snow RW, Berendt AR, Marsh K, Newbold CI (1997) A high frequency African coding polymorphism in the n-terminal domain of ICAM-1 predisposing to cerebral malaria in Kenya. Hum Mol Genet 6: 1357-1360

28 Beutler B, Kronchin N, Milsark IW, Goldberg A, Cerami A (1986) Induction of cachectin (tumor necrosis factor) synthesis by influenza virus: deficient production by endotoxin-resistant (C3H/HEJ) macrophages. Clin Res 34: 491A

29 Cheung CY, Poon LLM, Lau AS, Luk W, Lau YL, Shortridge KF, Gordon S, Guan Y, Peiris JSM (2002) Induction of proinflammatory cytokines in human macrophages by influenza A (H5N1) viruses: a mechanism for the unusual severity of human disease. Lancet 360: 1831-1837

30 Spriggs DR, Sherman ML, Michie H, Arthur KA, Imamura K, Wilmore D, Frei E, Kufe DW (1988) Recombinant human tumor necrosis factor administered as a 24-hour intravenous infusion. A phase 1 and pharmacologic study. $J$ Natl Cancer Inst 80: 1039-1044

31 Stevenson MM, Riley EM (2004) Innate immunity to malaria. Nat Rev Immunol 4: 169-180

32 Koch O, Awomoyi A, Usen S, Jallow M, Richardson A, Hull J, Pinder M, Newport M, Kwiatkowski D (2002) IFNGR1 gene promoter polymorphisms and susceptibility to cerebral malaria. J Infect Dis 185: 1684-1687

33 Aucan C, Walley AJ, Hennig BJ, Fitness J, Frodsham A, Zhang L, Kwiatkowski D, Hill AV (2003) Interferon-alpha receptor-1 (IFNAR1) variants are associated with protection against cerebral malaria in the Gambia. Genes Immun 4: 275-282

34 Walley AJ, Aucan C, Kwiatkowski D, Hill AVS (2004) Interleukin-1 gene cluster polymorphisms and susceptibility to clinical malaria in a Gambian case-control study. Eur J Hum Genet 12: 132-138

35 Luoni G, Verra F, Arca B, Sirima BS, Troye Blomberg M, Coluzzi M, Kwiatkowski D, Modiano D (2001) Antimalarial antibody levels and IL-4 polymorphism in the Fulani of West Africa. Genes Immun 2: 411-414

36 Wilson JN, Rockett K, Jallow M, Pinder M, Sisay Joof F, Newport M, Newton J, Kwiatkowski D (2005) Analysis of IL10 haplotypic associations with severe malaria. Genes Immun 6: 462-466

37 Wang HC, Bloom O, Zhang MH, Vishnubhakat JM, Ombrellino M, Che JT, Frazier A, Yang H, Ivanova S, Borovikova L et al (1999) HMG-1 as a late mediator of endotoxin lethality in mice. Science 285: 248-251

38 Andersson U, Wang HC, Palmblad K, Aveberger AC, Bloom O, ErlandssonHarris H, Janson A, Kokkola R, Zhang MH, Yang H, Tracey KJ (2000) High mobility group 1 protein (HMG-1) stimulates proinflammatory cytokine synthesis in human monocytes. $J$ Exp Med 192: 565-570

39 Ulloa L, Fink MP, Tracey KJ (2003) Ethyl pyruvate protects against lethal 
systemic inflammation by preventing HMGB1 release. Ann NY Acad Sci 987: 319-321

40 Mantell LL, Parrish WR, Ulloa L (2006) HMGB-1 as a therapeutic target for infectious and inflammatory disorders. Shock 25: 4-11

41 Alleva LM, Yang H, Tracey KJ, Clark IA (2005) High mobility group box 1 (HMGB1) protein: possible amplification signal in the pathogenesis of falciparum malaria. Trans $R$ Soc Trop Med Hyg 99: 171-175

42 Clark IA, Hunt NH, Butcher GA, Cowden WB (1987) Inhibition of murine malaria (Plasmodium chabaudi) in vivo by recombinant interferon-gamma or tumor necrosis factor, and its enhancement by butylated hydroxyanisole. $J$ Immunol 139: 3493-3496

43 Rockett KA, Awburn MM, Cowden WB, Clark IA (1991) Killing of Plasmodium falciparum in vitro by nitric oxide derivatives. Infect Immun 59: 3280-3283

44 Muniz-Junqueira MI, dos Santos-Neto LL, Tosta CE (2001) Influence of tumor necrosis factor-alpha on the ability of monocytes and lymphocytes to destroy intraerythrocytic Plasmodium falciparum in vitro. Cell Immunol 208: 73-79

45 Pombo DJ, Lawrence G, Hirunpetcharat C, Rzepczyk C, Bryden M, Cloonan N, Anderson K, Mahakunkijcharoen Y, Martin LB, Wilson D (2002) Immunity to malaria after administration of ultra-low doses of red cells infected with Plasmodium falciparum. Lancet 360: 610-617

46 Van Hensbroek MB, Palmer A, Onyiorah E, Schneider G, Jaffar S, Dolan G, Memming H, Frenkel J, Enwere G, Bennett S et al (1996) The effect of a monoclonal antibody to tumor necrosis factor on survival from childhood cerebral malaria. J Infect Dis 174: 1091-1097

47 Fisher CJ, Agosti JM, Opal SM, Lowry SF, Balk RA, Sadoff JC, Abraham E, Schein RMH, Benjamin E (1996) Treatment of septic shock with the tumor necrosis factor receptor: Fc fusion protein. N Engl J Med 334: 1697-1702

48 Clark IA, Alleva LE, Mills AC, Cowden WB (2004) Disease pathogenesis in malaria and clinically similar conditions. Clin Microbiol Rev 17: 509-539

49 Spriggs DR, Sherman ML, Kufe DW, Frei E (1987) Tumour necrosis factor and related cytokines. Ciba Found Symp 131: 206-227

50 Creagan ET, Kovach JS, Moertel CG, Frytak S, Kvols LK (1988) A phase 1 clinical trial of recombinant human tumor necrosis factor. Cancer 62: 2467-2471

51 Luxemburger C, Nosten F, Kyle DE, Kiricharoen L, Chongsuphajaisiddhi T, White NJ (1998) Clinical features cannot predict a diagnosis of malaria or differentiate the infecting species in children living in an area of low transmission. Trans $R$ Soc Trop Med Hyg 92: 45-49

52 Barnwell JW, Asch AS, Nachman RL, Yamaya M, Aikawa M, Ingravallo P (1989) A human 88-kD membrane glycoprotein (CD36) functions in vitro as a receptor for a cytoadherence ligand on Plasmodium falciparum-infected erythrocytes. J Clin Invest 84: 765-772

53 Roberts DD, Sherwood JA, Spitalnik SL, Panton LJ, Howard RJ, Dixit VM, Frazier WA, Miller LH, Ginsburg V (1985) Thrombospondin binds falciparum malaria parasitized erythrocytes and may mediate cytoadherence. Nature 318: 64-66

54 Newbold C, Warn P, Black G, Berendt A, Craig A, Snow B, Msobo M, Peshu N, 
Marsh K (1997) Receptor-specific adhesion and clinical disease in Plasmodium falciparum. Am J Trop Med Hyg 57: 389-398

55 Berendt AR, Simmons DL, Tansey J, Newbold CI, Marsh K (1989) Intercellular adhesion molecule- 1 is an endothelial cell adhesion receptor for Plasmodium falciparum. Nature 341: 57-59

56 Ockenhouse CF, Tegoshi T, Maeno Y, Benjamin C, Ho M, Kan KE, Thway Y, Win K, Aikawa M, Lobb RR (1992) Human vascular endothelial cell adhesion receptors for Plasmodium falciparum-infected erythrocytes: roles for endothelial leukocyte adhesion molecule 1 and vascular cell adhesion molecule 1.J Exp Med 176: 1183-1189

57 Carlson J, Helmby H, Hill AVS, Brewster D, Greenwood BM, Wahlgren M (1990) Human cerebral malaria: associated with erythrocyte rosetting and lack of anti-rosetting antibodies. Lancet 336: 1457-1460

58 Pain A, Ferguson DJP, Kai O, Urban BC, Lowe B, Marsh K, Roberts DJ (2001) Platelet-mediated clumping of Plasmodium falciparum-infected erythrocytes is a common adhesive phonotype and is associated with severe malaria. Proc Natl Acad Sci USA 98: 1805-1810

59 Pain A, Urban BC, Kai O, Casals-Pascual C, Shafi J, Marsh K, Roberts DJ (2001) A non-sense mutation in $\mathrm{Cd} 36$ gene is associated with protection from severe malaria. Lancet 357: 1502-1503

60 Jakobsen PH, Morris-Jones S, Hviid L, Theander TG, Elhassan IM, Bygbjerg IC, Greenwood BM, Ronn A (1994) Increased plasma concentrations of sICAM-1, sVCAM-1 and sELAM-1 in patients with Plasmodium falciparum or P. vivax malaria and association with disease severity. Immunology 83: 665-669

61 Esmon CT (1999) Possible involvement of cytokines in diffuse intravascular coagulation and thrombosis. Baill Best Pract Clin Haematol 12: 343-359

62 Levi M, van der Poll T, ten Cate H (2006) Tissue factor in infection and severe inflammation. Semin Thromb Hemost 32: 33-39

63 Bajaj MS, Kuppuswamy MN, Manepalli AN, Bajaj SP (1999) Transcriptional expression of tissue factor pathway inhibitor, thrombomodulin and von Willebrand factor in normal human tissues. Thromb Haemost 82: 1047-1052

64 Kaplanski G, Marin V, Fabrigoule M, Boulay V, Benoliel AM, Bongrand P, Kaplanski S, Farnarier C (1998) Thrombin-activated human endothelial cells support monocyte adhesion in vitro following expression of intercellular adhesion molecule-1 (ICAM-1 CD54) and vascular cell adhesion molecule-1 (VCAM-1 CD106). Blood 92: 1259-1267

65 Marra F, Grandaliano G, Valente AJ, Abboud HE (1995) Thrombin stimulates proliferation of liver fat-storing cells and expression of monocyte chemotactic protein-1: potential role in liver injury. Hepatology 22: 780-787

66 English M, Muambi B, Mithwani S, Marsh K (1997) Lactic acidosis and oxygen debt in African children with severe anaemia. Q J Med 90: 563-569

67 Scharte M, Fink MP (2003) Red blood cell physiology in critical illness. Crit Care Med 31: S651-S657

68 Taverne J, Sheikh N, Desouza JB, Playfair JHL, Probert L, Kollias J (1994) Anaemia and resistance to malaria in transgenic mice expressing human tumour necrosis factor. Immunology 82: 397-403 
69 Overmann RR, Hill TS, Wong YT (1949) Physiological studies in the human malarial host. J Nat Malaria Soc 8: 14-31

70 Dunn MJ (1969) Alterations in red blood cell sodium transport during malaria. $J$ Clin Invest 48: 674-684

71 Illner H, Shires GT (1982) Changes in sodium, potassium, and adenosine triphosphate contents of red blood cells in sepsis and septic shock. Circ Shock 9: 259-267

72 Guzman NJ, Fang MZ, Tang SS, Ingelfinger JR, Garg LC (1995) Autocrine inhibition of $\mathrm{Na}^{+} / \mathrm{K}^{+}$-ATPase by nitric oxide in mouse proximal tubule epithelial cells. J Clin Invest 95: 2083-2088

73 Bateman RM, Jagger JE, Sharpe MD, Ellsworth ML, Mehta S, Ellis CG (2001) Erythrocyte deformability is a nitric oxide-mediated factor in decreased capillary density during sepsis. Am J Physiol 280: H2848-H2856

74 Wambach G, Overhoff U, Hossmann V (1985) Sodium transport and red cell deformability. Klin Wochenschr 3: 35-37

75 Scharte M, Fink MP (2003) Red blood cell physiology in critical illness. Crit Care Med 31: S651-S657

76 Lee MV, Ambrus JL, DeSouza JM, Lee RV (1982) Diminished red blood cell deformability in uncomplicated human malaria. A preliminary report. $J$ Med 13: 479-485

77 Rogers F, Dunn R, Barrett J, Merlotti G, Sheaff C, Nolan P (1985) Alterations of capillary flow during sepsis. Circ Shock 15: 105-110

78 Hurd TC, Dasmahapatra KS, Rush BF Jr, Machiedo GW (1988) Red blood cell deformability in human and experimental sepsis. Arch Surg 123: 217-220

79 Dondorp AM, Angus BJ, Hardeman MR, Chotivanich KT, Silamut K, Ruangveerayuth R, Kager PA, White NJ, Vreeken J (1997) Prognostic significance of reduced red blood cell deformability in severe falciparum malaria. Am J Trop Med Hyg 57: 507-511

80 Dondorp AM, Angus BJ, Chotivanich K, Silamut K, Ruangveerayuth R, Hardeman MR, Kager PA, Vreeken J, White NJ (1999) Red blood cell deformability as a predictor of anemia in severe falciparum malaria. Am J Trop Med Hyg 60: 733-737

81 Srichaikul T, Panikbutr N, Jeumtrakul P (1967) Bone marrow changes in human malaria. Ann Trop Med Parasitol 61: 40-51

82 Dörmer P, Dietrich M, Kern P, Horstmann RD (1983) Ineffective erythropoiesis in acute human P. falciparum malaria. Blut 46: 279-288

83 Wickramasinghe SN, Phillips RE, Looareesuwan S, Warrell DA, Hughes M (1987) The bone marrow in human cerebral malaria: parasite sequestration within sinusoids. Br J Haematol 66: 295-306

84 Wickramasinghe SN, Looareesuwan S, Nagachinta B, White NJ (1989) Dyserythropoiesis and ineffective erythropoiesis in Plasmodium vivax malaria. Br J Haematol 72: 91-99

85 Sassa S, Kawakami M, Cerami A (1983) Inhibiton of the growth and differentiation of erythroid precursor cells by an endotoxin-induced mediator from peritoneal macrophages. Proc Natl Acad Sci USA 80:1717-1720

86 Beutler B, Greenwald D, Hulmes JD, Chang M, Pan YC, Mathison J, Ulevitch 
R, Cerami A (1985) Identity of tumour necrosis factor and the macrophagesecreted factor cachectin. Nature 316: 552-554

87 Clark IA, Chaudhri G (1988) Tumour necrosis factor may contribute to the anaemia of malaria by causing dyserythropoiesis and erythrophagocytosis. $\mathrm{Br} \mathrm{J}$ Haematol 70: 99-103

88 Othoro C, Lal AA, Nahlen B, Koech D, Orago AS, Udhayakumar V (1999) A low interleukin-10 tumor necrosis factor-alpha ratio is associated with malaria anemia in children residing in a holoendemic malaria region in western Kenya. J Infect Dis 179: 279-282

89 Perkins DJ, Weinberg JB, Kremsner PG (2000) Reduced interleukin-12 and transforming growth factor-beta1 in severe childhood malaria: relationship of cytokine balance with disease severity. J Infect Dis 182: 988-992

90 May J, Lell B, Luty AJ, Meyer CG, Kremsner PG (2000) Plasma interleukin-10: tumor necrosis factor (TNF)-alpha ratio is associated with TNF promoter variants and predicts malarial complications. J Infect Dis 182: 1570-1573

91 Dodoo D, Omer FM, Todd J, Akanmori BD, Koram KA, Riley EM (2002) Absolute levels and ratios of proinflammatory and anti-inflammatory cytokine production in vitro predict clinical immunity to Plasmodium falciparum malaria. J Infect Dis 185: 971-979

92 Luty AJ, Perkins DJ, Lell B, Schmidt Ott R, Lehman LG, Luckner D, Greve B, Matousek P, Herbich K, Schmid D et al (2000) Low interleukin-12 activity in severe Plasmodium falciparum malaria. Infect Immun 68: 3909-3915

93 Issifou S, Mavoungou E, Borrmann S, Bouyou Akotet MK, Matsiegui PB, Kremsner PG, Ntoumi F (2003) Severe malarial anemia associated with increased soluble Fas ligand (sFasL) concentrations in Gabonese children. Eur Cytokine Netw 14: 238-241

94 Helleberg M, Goka BQ, Akanmori BD, Obeng Adjei G, Rodriques O, Kurtzhals JA (2005) Bone marrow suppression and severe anaemia associated with persistent Plasmodium falciparum infection in African children with microscopically undetectable parasitaemia. Malaria $J$ 4: 56

95 Martiney JA, Sherry B, Metz CN, Espinoza M, Ferrer AS, Calandra T, Broxmeyer HE, Bucala R (2000) Macrophage migration inhibitory factor release by macrophages after ingestion of Plasmodium chabaudi-infected erythrocytes: Possible role in the pathogenesis of malarial anemia. Infect Immun 68: 2259-2267

96 McDevitt MA, Xie J, Shanmugasundaram G, Griffith J, Liu A, McDonald C, Thuma P, Gordeuk VR, Metz CN, Mitchell R et al (2006) A critical role for the host mediator macrophage migration inhibitory factor in the pathogenesis of malarial anemia. J Exp Med 203: 1185-1196

97 Fink MP (2001) Cytopathic hypoxia. Mitochondrial dysfunction as mechanism contributing to organ dysfunction in sepsis. Crit Care Clin 17: 219-237

98 Hotchkiss RS, Rust RS, Dence CS, Wasserman TH, Song SK, Hwang DR, Karl IE, Welch MJ (1991) Evaluation of the role of cellular hypoxia in sepsis by the hypoxic marker [ $\left.{ }^{18} \mathrm{~F}\right]$ fluoromisonidazole. Am J Physiol 261: R965-R972

99 Boekstegers P, Weidenhofer S, Kapsner T, Werdan K (1994) Skeletal muscle partial pressure of oxygen in patients with sepsis. Crit Care Med 22: 640-650 
100 Fink M (1997) Cytopathic hypoxia in sepsis. Acta Anaesthesiol Scand 110: 87-95

101 L'Her E, Sebert P (2001) A global approach to energy metabolism in an experimental model of sepsis. Am J Respir Crit Care Med 164: 1444-1447

102 Brealey D, Karyampudi S, Jacques TS, Novelli M, Stidwill R, Taylor V, Smolenski RT, Singer M (2004) Mitochondrial dysfunction in a long-term rodent model of sepsis and organ failure. Am J Physiol 286: R491-497

103 Brealey D, Brand M, Hargreaves I, Heales S, Land J, Smolenski R, Davies NA, Cooper CE, Singer M (2002) Association between mitochondrial dysfunction and severity and outcome of septic shock. Lancet 360: 219-223

104 Svistunenko DA, Davies N, Brealey D, Singer M, Cooper CE (2006) Mitochondrial dysfunction in patients with severe sepsis: An EPR interrogation of individual respiratory chain components. Biochim Biophys Acta 1757: 262-272

105 Kern P, Hemmer CJ, Van Damme J, Gruss HJ, Dietrich M (1989) Elevated tumour necrosis factor alpha and interleukin-6 serum levels as markers for complicated Plasmodium falciparum malaria. Am J Med 87: 139-143

106 Kwiatkowski D, Hill AVS, Sambou I, Twumasi P, Castracane J, Manogue KR, Cerami A, Brewster DR, Greenwood BM (1990) TNF concentration in fatal cerebral, non-fatal cerebral, and uncomplicated Plasmodium falciparum malaria. Lancet 336: 1201-1204

107 Nicholls DG (2004) Mitochondrial dysfunction and glutamate excitotoxicity studied in primary neuronal cultures. Curr Mol Med 4: 149-177

108 Riley MV, Maegraith BG (1962) A factor in the serum of malaria-infected animals capable of inhibiting the in vitro oxidative metabolism of normal liver mitochondria. Ann Trop Med Parasitol 55: 489-497

109 Thurnham DI, Fletcher KA, Maegraith BG (1971) The inhibition of mitochondrial respiration and oxidative phosphorylation by serum from malaria-infected animals. II. The inhibitory activity of serum ultrafitrates from Plasmodium knowlesi-infected monkeys. Ann Trop Med Parasitol 65: 287-295

110 Maegraith B, Fletcher A (1972) The pathogenesis of mammalian malaria. $A d v$ Parasitol 10: 49-75

111 Taylor TE, Borgstein A, Molyneux ME (1993) Acid-base status in paediatric Plasmodium falciparum malaria. Q J Med 86: 99-109

112 Krishna S, Waller DW, Terkuile F, Kwiatkowski D, Crawley J, Craddock CFC, Nosten F, Chapman D, Brewster D, Holloway PA, White NJ (1994) Lactic acidosis and hypoglycaemia in children with severe malaria - pathophysiological and prognostic significance. Trans $R$ Soc Trop Med Hyg 88: 67-73

113 Aiyathurai JE, Wong HB, Quak SH, Jacob E, Chio LF, Sothy SP (1983) The significance of type B hyperlactataemia in infective encephalopathy. Ann Acad Med Singapore 12: 115-125

114 Sasi P, English M, Berkley J, Lowe B, Shebe M, Mwakesi R, Kokwaro G (2006) Characterisation of metabolic acidosis in Kenyan children admitted to hospital for acute non-surgical conditions. Trans R Soc Trop Med Hyg 100: 401-409

115 Dennis SC, Gevers W, Opie LH (1991) Protons in ischemia: where do they come from; where do they go to? J Mol Cell Cardiol 23: 1077-1086 
116 Hotchkiss RS, Karl IE (1992) Reevaluation of the role of cellular hypoxia and bioenergetic failure in sepsis. JAMA 267: 1503-1510

117 Fink MP (1996) Does tissue acidosis in sepsis indicate tissue hypoperfusion? Intens Care Med 22: 1144-1146

118 Deshpande SA, Platt MP (1997) Association between blood lactate and acidbase status and mortality in ventilated babies. Arch Dis Child 76: F15-F20

119 Azimi G, Vincent JL (1986) Ultimate survival from septic shock. Resuscitation 14: $245-53$

120 White NJ, Warrell DA, Chanthavanich P, Looareesuwan S, Warrell MJ, Krishna S, Williamson DH, Turner RC (1983) Severe hypoglycemia and hyperinsulinemia in falciparum malaria. $N$ Engl J Med 309: 61-66

121 Planche T (2005) Malaria and fluids - balancing acts. Trends Parasitol 21: 562-567

122 Krishna S, Taylor AM, Supanaranond W, Pukrittayakamee S, ter Kuile F, Tawfiq KM, Holloway PAH, White NJ (1999) Thiamine deficiency and malaria in adults from southeast Asia. Lancet 353: 546-549

123 Kreisberg RA (1980) Lactate homeostasis and lactic acidosis. Ann Intern Med 92: 227-237

124 Gutierrez G, Wulf ME (2005) Lactic acidosis in sepsis: another commentary. Crit Care Med 33: 2420-2422

125 Krishna S, Supanaranond W, Pukrittayakamee S, Karter D, Supputamongkol Y, Davis TM, Holloway PA, White NJ (1994) Dichloroacetate for lactic acidosis in severe malaria: a pharmacokinetic and pharmacodynamic assessment. Metabolism 43: 974-981

126 Stacpoole PW, Wright EC, Baumgartner TG, Bersin RM, Buchalter S, Curry SH, Duncan CA, Harman EM, Henderson GN, Jenkinson S et al (1992) A controlled clinical trial of dichloroacetate for treatment of lactic acidosis in adults. N Engl J Med 327: 1564-1569

127 Maran A, Cranston I, Lomas J, Macdonald I, Amiel SA (1994) Protection by lactate of cerebral function during hypoglycaemia. Lancet 343: 16-20

128 Schurr A, Payne RS, Miller JJ, Rigor BM (1997) Brain lactate, not glucose, fuels the recovery of synaptic function from hypoxia upon reoxygenation: an in vitro study. Brain Res 744: 105-111

129 King P, Parkin H, Macdonald IA, Barber C, Tattersall RB (1997) The effect of intravenous lactate on cerebral function during hypoglycaemia. Diabet Med 14: 19-28

130 Pellerin L (2003) Lactate as a pivotal element in neuron-glia metabolic cooperation. Neurochem Int 43: 331-338

131 Mecher C, Rackow EC, Astiz ME, Weil MH (1991) Unaccounted for anion in metabolic acidosis during severe sepsis in humans. Crit Care Med 19: 705-711

132 Balasubramanyan N, Havens PL, Hoffman GM (1999) Unmeasured anions identified by the Fencl-Stewart method predict mortality better than base excess, anion gap, and lactate in patients in the pediatric intensive care unit. Crit Care Med 27: 1577-1581

133 Dondorp AM, Chau TTH, Phu NH, Mai NTH, Loc PP, Van Chuong L, Sinh DX, Taylor A, Hien TT, White NJ, Day NPJ (2004) Unidentified acids of strong prognostic significance in severe malaria. Crit Care Med 32: 1683-1688 
134 Dekker E, Hellerstein MK, Romijn JA, Neese RA, Peshu N, Endert E, Marsh K, Sauerwein HP (1997) Glucose homeostasis in children with falciparum malaria: precursor supply limits gluconeogenesis and glucose production. J Clin Endocrinol Metab 82: 2514-2521

135 Miller SI, Wallace RJ, Musher DM, Septimus EJ, Kohl S, Baughn RE (1980) Hypoglycemia as a manifestation of sepsis. Am J Med 68: 649-654

136 Phillips RE (1989) Hypoglycaemia is an important complication of falciparum malaria. Q J Med 71: 477-483

137 Beales PF, Brabin B, Dorman E, Gilles HM, Loutain L, Marsh K, Molyneux ME, Olliaro P, Schapira A, Touze JE et al (2000) Severe falciparum malaria. Trans R Soc Trop Med Hyg 94: S1-S90

138 Waller D, Crawley J, Nosten F, Chapman D, Krishna S, Craddock C, Brewster D, White NJ (1991) Intracranial pressure in childhood cerebral malaria. Trans $R$ Soc Trop Med Hyg 85: 362-364

139 Newton CRJC, Crawley J, Sowumni A, Waruiru C, Mwangi I, English M, Murphy S, Winstanley PA, Marsh K, Kirkham FJ (1997) Intracranial hypertension in Africans with cerebral malaria. Arch Dis Child 76: 219-226

140 Beare NA, Southern C, Chalira C, Taylor TE, Molyneux ME, Harding SP (2004) Prognostic significance and course of retinopathy in children with severe malaria. Arch Ophthalmol 122: 1141-1147

141 Gitau EN, Newton CR (2005) Blood-brain barrier in falciparum malaria. Trop Med Int Health 10: 285-292

142 Adams S, Brown H, Turner G (2002) Breaking down the blood-brain barrier: signaling a path to cerebral malaria? Trends Parasitol 18: 360-366

143 Brown H, Hien TT, Day N, Mai N, Chuong LV, Chau T, Loc PP, Phu NH, Bethell D, Farrar J et al (1999) Evidence of blood-brain barrier dysfunction in human cerebral malaria. Neuropathol Appl Neurobiol 25: 331-340

144 Warrell DA, Looareesuwan S, Phillips RE, White NJ, Warrell MJ, Chapel HM, Areekul S, Tharavanij S (1986) Function of the blood-cerebrospinal fluid barrier in human cerebral malaria: rejection of the permeability hypothesis. Am J Trop Med Hyg 35: 882-889

145 Brown HC, Chau TTH, Mai NTH, Day NPJ, Sinh DX, White NJ, Hien TT, Farrar J, Turner GDH (2000) Blood-brain barrier function in cerebral malaria and CNS infections in Vietnam. Neurology 55: 104-111

146 Unterberg AW, Stover J, Kress B, Kiening KL (2004) Edema and brain trauma. Neuroscience 129: 1021-1029

147 Idro R, Bitarakwate E, Tumwesigire S, John CC (2005) Clinical manifestations of severe malaria in the highlands of southwestern Uganda. Am J Trop Med Hyg 72: 561-567

148 English M, Newton CR (2002) Malaria: pathogenicity and disease. Chem Immunol 80: 50-69

149 Salih MA, Abdel Gader AG, Al Jarallah AA, Kentab AY, Al Nasser MN (2006) Outcome of stroke in Saudi children. Saudi Med J 27: S91-S96

150 Newton CRJC, Peshu N, Kendall B, Kirkham FJ, Sowunmi A, Waruiru C, Mwangi I, Murphy SA, Marsh K (1994) Brain swelling and ischaemia in Kenyans with cerebral malaria. Arch Dis Child 70: 281-287

151 Clark IA, Awburn MM, Whitten RO, Harper CG, Liomba NG, Molyneux ME, 
Taylor TE (2003) Tissue distribution of migration inhibitory factor and inducible nitric oxide synthase in falciparum malaria and sepsis in African children. Malaria J 2: 6

152 Clark IA, Awburn MM, Harper CG, Liomba NG, Molyneux ME (2003) Induction of HO-1 in tissue macrophages and monocytes in fatal falciparum malaria and sepsis. Malaria $J$ 2: 41

153 Kwiatkowski D, Cannon JG, Manogue KR, Cerami A, Dinarello CA, Greenwood BM (1989) Tumor necrosis factor production in falciparum malaria and its association with schizont rupture. Clin Exp Immunol 77: 361-366

154 Akanmori BD, Kurtzhals JAL, Goka BQ, Adabayeri V, Ofori MF, Nkrumah FK, Behr C, Hviid L (2000) Distinct patterns of cytokine regulation in discrete clinical forms of Plasmodium falciparum malaria. Eur Cytokine Net 11: 113-118

155 Gimenez F, de Lagerie SB, Fernandez C, Pino P, Mazier D (2003) Tumor necrosis factor alpha in the pathogenesis of cerebral malaria. Cell Mol Life Sci 60: 1623-1635

156 McGuire W, Hill AVS, Allsopp CEM, Greenwood BM, Kwiatkowski D (1994) Variation in the TNF-alpha promoter region associated with susceptibility to cerebral malaria. Nature 371: 508-511

157 Clark IA, Rockett KA, Cowden WB (1992) Possible central role of nitric oxide in conditions clinically similar to cerebral malaria. Lancet 340: 894-896

158 Schweizer M, Richter C (1994) Nitric oxide potently and reversibly deenergizes mitochondria at low oxygen tension. Biochem Biophys Res Commun 204: 169-175

159 Currier AR, Ziegler MH, Riley MM, Babcock TA, Telbis VP, Carlin JM (2000) Tumor necrosis factor-alpha and lipopolysaccharide enhance interferoninduced antichlamydial indoleamine dioxygenase activity independently. $J$ Interferon Cytokine Res 20: 369-376

160 Fujigaki S, Saito K, Sekikawa K, Tone S, Takikawa O, Fujii H, Wada H, Noma A, Seishima M (2001) Lipopolysaccharide induction of indoleamine 2,3-dioxygenase is mediated dominantly by an IFN-gamma-independent mechanism. Eur J Immunol 31: 2313-2318

161 Medana IM, Day NPJ, Salahifar-Sabet H, Stocker R, Smythe G, Bwanaisa L, Njobvu A, Kayira K, Turner GDH, Taylor TE, Hunt NH (2003) Metabolites of the kynurenine pathway of tryptophan metabolism in the cerebrospinal fluid of Malawian children with malaria. J Infect Dis 188: 844-849

162 Dobbie M, Crawley J, Waruiru C, Marsh K, Surtees R (2000) Cerebrospinal fluid studies in children with cerebral malaria: An excitotoxic mechanism? Am J Trop Med Hyg 62: 284-290

163 Clark IA, Al Yaman FM, Cowden WB, Rockett KA (1996) Does malarial tolerance, through nitric oxide, explain the low incidence of autoimmune disease in tropical Africa. Lancet 348: 1492-1494

164 Mendis KN, Carter R (1992) The role of cytokines in Plasmodium vivax malaria. Mem Inst Oswaldo Cruz 87: 51-55

165 Young GB, Bolton CF, Austin TW, Archibald YM, Gonder J, Wells GA (1990) The encephalopathy associated with septic illness. Clin Invest Med 13: 297-304

166 Yang YL, Li JP, Li KZ, Dou KF (2004) Tumor necrosis factor alpha antibody 
prevents brain damage of rats with acute necrotizing pancreatitis. World $J$ Gastroenterol 10: 2898-2900

167 Wilson JX, Young GB (2003) Progress in clinical neurosciences: sepsis-associated encephalopathy: evolving concepts. Can J Neurol Sci 30: 98-105

168 van Zeijl JH, Bakkers J, Wilbrink B, Melchers WJG, Mullaart RA, Galama JMD (2005) Influenza-associated encephalopathy: No evidence for neuroinvasion by influenza virus nor for reactivation of human herpesvirus 6 or 7. Clin Infect Dis 40: 483-485

169 Morishima T, Togashi T, Yokota S, Okuno Y, Miyazaki C, Tashiro M, Okabe N (2002) Encephalitis and encephalopathy associated with an influenza epidemic in Japan. Clin Infect Dis 35: 512-517

170 Ichiyama T, Isumi H, Ozawa H, Matsubara T, Morishima T, Furukawa S (2003) Cerebrospinal fluid and serum levels of cytokines and soluble tumor necrosis factor receptor in influenza virus-associated encephalopathy. Scand J Infect Dis 35: 59-61

171 Ichiyama T, Morishima T, Isumi H, Matsufuji H, Matsubara T, Furukawa S (2004) Analysis of cytokine levels and NF-[kappa]B activation in peripheral blood mononuclear cells in influenza virus-associated encephalopathy. Cytokine 27: 31-37

172 Hosoya M, Nunoi H, Aoyama M, Kawasaki Y, Suzuki H (2005) Cytochrome $\mathrm{c}$ and tumor necrosis factor-alpha values in serum and cerebrospinal fluid of patients with influenza-associated encephalopathy. Pediatr Infect Dis J 24: 467-470

173 Kawashima H, Watanabe Y, Ichiyama T, Mizuguchi M, Yamada N, Kashiwagi Y, Takekuma K, Hoshika A, Mori T (2002) High concentration of serum nitrite/ nitrate obtained from patients with influenza-associated encephalopathy. Pediatr Int 44: 705-707

174 Nakai Y, Itoh M, Mizuguchi M, Ozawa H, Okazaki E, Kobayashi Y, Takahashi M, Ohtani K, Ogawa A, Narita M (2003) Apoptosis and microglial activation in influenza encephalopathy. Acta Neuropathol (Berl) 105: 233-239

175 Idro R, Jenkins NE, Newton CR (2005) Pathogenesis, clinical features, and neurological outcome of cerebral malaria. Lancet Neurol 4: 827-840

176 Lang B, Newbold CI, Williams G, Peshu N, Marsh K, Newton C (2005) Antibodies to voltage-gated calcium channels in children with falciparum malaria. J Infect Dis 191: 117-121

177 Haldane JBS (1948) The rate of mutation of human genes. Hereditas 35 (Suppl): 267-273

178 Hill AV, Allsopp CE, Kwiatkowski D, Anstey NM, Twumasi P, Rowe PA, Bennett S, Brewster D, McMichael AJ, Greenwood BM (1991) Common west African HLA antigens are associated with protection from severe malaria. Nature 352: 595-600

179 Agarwal A, Guindo A, Cissoko Y, Taylor JG, Coulibaly D, Kone A, Kayentao K, Djimde A, Plowe CV, Doumbo O et al (2000) Hemoglobin C associated with protection from severe malaria in the Dogon of Mali, a West African population with a low prevalence of hemoglobin S. Blood 96: 2358-2363

180 Modiano D, Luoni G, Sirima BS, Simpore J, Verra F, Konate A, Rastrelli E, 
Olivieri A, Calissano C, Paganotti GM et al (2001) Haemoglobin C protects against clinical Plasmodium falciparum malaria. Nature 414: 305-308

181 Hutagalung R, Wilairatana P, Looareesuwan S, Brittenham GM, Aikawa H, Gordeuk VR (1999) Influence of hemoglobin E trait on the severity of falciparum malaria. J Infect Dis 179: 283-286

182 Ruwende C, Khoo SC, Snow AW, Yates SNR, Kwiatkowski D, Gupta S, Warn P, Allsopp CEM, Gilbert SC, Peschu N et al (1995) Natural selection of hemi- and heterozygotes for G6PD deficiency in Africa by resistance to severe malaria. Nature 376: 246-249

183 Pasvol G, Weatherall DJ, Wilson RJ (1978) Cellular mechanism for the protective effect of haemoglobin S against P. falciparum malaria. Nature 274: 701-703

184 Cappadoro M, Giribaldi G, Obrien E, Turrini F, Mannu F, Ulliers D, Simula G, Luzzatto L, Arese P (1998) Early phagocytosis of glucose-6-phosphate dehydrogenase (G6PD)-deficient erythrocytes parasitized by Plasmodium falciparum may explain malaria protection in G6PD deficiency. Blood 92: 2527-2534

185 Abu-Zeid YA, Abdulhadi NH, Hviid L, Theander TG, Saeed BO, Jepsen S, Jensen JB, Bayoumi RA (1991) Lymphoproliferative responses to Plasmodium falciparum antigens in children with and without the sickle cell trait. Scand J Immunol 34: 237-242

186 Fairhurst RM, Baruch DI, Brittain NJ, Ostera GR, Wallach JS, Hoang HL, Hayton K, Guindo A, Makobongo MO, Schwartz OM et al (2005) Abnormal display of PfEMP-1 on erythrocytes carrying haemoglobin $\mathrm{C}$ may protect against malaria. Nature 435: 1117-1121

187 Ringelhann B, Hathorn MK, Jilly P, Grant F, Parniczky G (1976) A new look at the protection of hemoglobin AS and AC genotypes against Plasmodium falciparum infection: a census tract approach. Am J Hum Genet 28: 270-279

188 Mockenhaupt FP, Ehrhardt S, Cramer JP, Otchwemah RN, Anemana SD, Goltz K, Mylius F, Dietz E, Eggelte TA, Bienzle U (2004) Hemoglobin C and resistance to severe malaria in Ghanaian children. J Infect Dis 190: 1006-1009

189 Duffy PE, Fried M (2006) Red blood cells that do and red blood cells that don't: how to resist a persistent parasite. Trends Parasitol 22: 99-101

190 Wambua S, Mwangi TW, Kortok M, Uyoga SM, Macharia AW, Mwacharo JK, Weatherall DJ, Snow RW, Marsh K, Williams TN (2006) The effect of alpha+thalassaemia on the incidence of malaria and other diseases in children living on the coast of Kenya. PLoS Med 3: e158

191 Williams TN, Maitland K, Bennett S, Ganczakowski M, Peto TEA, Newbold CI, Bowden DK, Weatherall DJ, Clegg JB (1996) High incidence of malaria in alpha-thalassaemic children. Nature 383: 522-525

192 Oguariri RM, Borrmann S, Klinkert MQ, Kremsner PG, Kun JFJ (2001) High prevalence of human antibodies to recombinant Duffy binding-like alpha domains of the Plasmodium falciparum-infected erythrocyte membrane protein 1 in semi-immune adults compared to that in non-immune children. Infect Immun 69: 7603-7609

193 Atkinson SH, Rockett K, Sirugo G, Bejon PA, Fulford A, O'Connell MA, Bailey R, Kwiatkowski DP, Prentice AM (2006) Seasonal childhood anaemia 
in West Africa is associated with the haptoglobin 2-2 genotype. PLoS Med 3: e172

194 Williams TN, Mwangi TW, Wambua S, Peto TEA, Weatherall DJ, Gupta S, Recker M, Penman BS, Uyoga S, Macharia A et al (2005) Negative epistasis between the malaria-protective effects of alpha(+)-thalassemia and the sickle cell trait. Nat Genet 37: 1253-1257

195 Yang H, Ochani M, Li J, Qiang X, Tanovic M, Harris HE, Susarla SM, Ulloa L, Wang H, DiRaimo R et al (2004) Reversing established sepsis with antagonists of endogenous high-mobility group box 1. Proc Natl Acad Sci USA 101: 296-301

196 Ulloa L, Ochani M, Yang H, Tanovic M, Halperin D, Yang R, Czura CJ, Fink MP, Tracey KJ (2002) Ethyl pyruvate prevents lethality in mice with established lethal sepsis and systemic inflammation. Proc Natl Acad Sci USA 99: 12351-12356

197 Maitland K, Pamba A, English M, Peshu N, Marsh K, Newton C, Levin M (2005) Randomized trial of volume expansion with albumin or saline in children with severe malaria: preliminary evidence of albumin benefit. Clin Infect Dis 40: 538-545

198 Krishna S, Agbenyega T, Angus BJ, Beduaddo G, Oforiamanfo G, Henderson G, Szwandt ISF, Obrien R, Stacpoole PW (1995) Pharmacokinetics and pharmacodynamics of dichloroacetate in children with lactic acidosis due to severe malaria. Q J Med 88: 341-349

199 Dondorp AM, Omodeo Sale F, Chotivanich K, Taramelli D, White NJ (2003) Oxidative stress and rheology in severe malaria. Redox Rep 8: 292-294

200 Watt G, Jongsakul K, Ruangvirayuth R (2002) A pilot study of N-acetylcysteine as adjunctive therapy for severe malaria. $Q J$ Med 95: 285-290

201 Wassmer SC, Cianciolo GJ, Combes V, Grau GE (2005) Inhibition of endothelial activation: a new way to treat cerebral malaria? PLoS Med 2: 885-890 